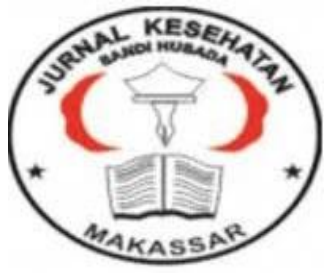

Jurnal Ilmiah Kesehatan Sandi Husada

hhttps://akper-sandikarsa.e-journal.id/JIKSH

Volume 9, Nomor 2, Desember 2020, pp 779-786

p-ISSN: 2354-6093 dan e-ISSN: 2654-4563

DOI: $10.35816 /$ jiskh.v10i2.399

\title{
Pengaruh Sanitasi Makanan dan Kontaminasi Bakteri Escherichia coli Terhadap Penyakit Diare
}

Effect of Food Sanitation and Escherichia coli Bacteria Contamination on Diarrhea

Dion Pardameian Hutasoit

Pendidikan Dokter, Fakultas Kedokteran Universitas Lampung

\section{Artikel info}

Artikel history:

Received; Juli 2020

Revised: Agustus 2020

Accepted; Agustus 2020

\begin{abstract}
Abstrak
Latar Belakang: Diare merupakan pengeluaran feses yang konsistensinya lembek hingga cair dengan frekuensi pengeluaran feses sebanyak tiga kali ataupun lebih dalam satu hari. Salah satu faktor resiko diare adalah sanitasi makanan yang tidak baik dan adanya kontaminasi mikroorganisme Escherichia coli. Tujuan: mengetahui lebih lanjut tentang pengaruh sanitasi makanan dan kontaminasi Escherichia coli terhadap penyakit diare. Metode: Menggunakan studi literatur dari jurnal baik nasional maupun internasional dengan cara meringkas topik pembahasan dan membandingkan hasil yang disajikan didalam artikel. Hasil: Sanitasi makanan berkaitan erat dengan higiene, dimana seseorang yang memiliki higiene yang baik harus didukung dengan sanitasi yang memadai. Pada manusia bakteri E. coli yang sering menyebabkan diare dikelompokkan menjadi empat, yaitu enterotoksigenik E. coli (ETEC), enteroinvasif E. coli (ETEC), enteropatogenik E. coli (EPEC), dan enterohemoragik E. coli (EHEC). Kesimpulan: Sanitasi makanan dan kontaminasi E. coli sangat berpengaruh pada kejadian penyakit diare.
\end{abstract}

\section{Abstract}

Background: Diarrhea is the consistency of feces that is softening to liquid with the frequency of production of feces three times or more in a day. One of the risk factors of diarrhea is the food sanitation is not good and the contamination of Escherichia coli microorganisms. Objectives: Learn more about the influence of food sanitation and Escherichia coli contamination to diarrhea disease. Methods: Using literary studies from both national and international journals by summarizing the topic of the discussion and comparing the results presented in the article. Results: Food sanitation is closely related to hygiene, where a person with good hygiene must be supported by adequate sanitation. In human bacteria E. coli that often 


causes diarrhea is grouped into four, namely
Enterotoksigenic E. coli (ETEC), enteroinvasive E. coli
(ETEC), Enteropatogenic E. coli (EPEC), and
Enterohemorrhagic E. coli (EHEC). Conclusion: food
sanitation and contamination of E. coli are very influential
in the incidence of diarrhea disease

\author{
Keywords: \\ Food Sanitation; \\ Escherichia coli; \\ Diarrhea;
}

Coresponden author:

Email: dionhutasoit12@gmail.com

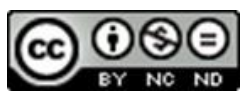

artikel dengan akses terbuka dibawah lisensi CC BY 4.0

Indonesia masih memiliki angka kematian akibat penyakit diare yang cukup tinggi. Hal ini dapat dilihat dari tingginya angka morbiditas dan juga penanganan pada penderita yang terlambat dilakukan. Survei morbiditas yang dilakukan Kementerian Kesehatan di Indonesia dari tahun 2000-2010 menunjukkan adanya insidensi penyakit diare yang cenderung naik. Pada tahun 2000, penduduk yang terserang penyakit diare merupakan 301 per 1000 penduduk dan tahun 2010 naik menjadi 411 per 1000 penduduk. Kejadian Luar Biasa (KLB) pada diare juga masih sering terjadi, dengan CFR (Case Fatality Rate) yang masih tinggi (Kemenkes RI, 2011). Diare merupakan penyebab kematian paling umum pada bayi dan balita. Diare menyebabkan status gizi buruk dan status gizi buruk serta menyebabkan kegagalan pertumbuhan, bahkan penurunan berat badan yang permanen akibat kehilangan cairan dan dehidrasi. Permasalahan yang dirasakan adalah buang air besar dengan konsistensi lunak atau cair, bahkan bisa dalam bentuk air saja dan frekuensinya lebih sering biasanya tiga kali atau lebih dalam satu hari (Arda, dkk, 2020).

Diare merupakan pengeluaran feses yang konsistensinya lembek hingga cair dengan frekuensi pengeluaran feses sebanyak tiga kali ataupun lebih dalam satu hari. Diare bisa menyebabkan demam, sakit perut, pengurangan nafsu makan, rasa letih serta penurunan berat badan. Diare bisa menimbulkan kehabisan cairan serta elektrolit secara tiba- tiba, sehingga bisa menyebabkan terjadinya berbagai macam komplikasi seperti kehilangan cairan tubuh, renjatan hipovolemik, kerusakan organ hingga menyebabkan koma (Lailatul, 2013). Penyebab utama diare umumnya adalah mikroba seperti Escherichia coli, Shigella, Rotavirus, Entamoeba histolytica, Salmonella sp, Yersinia sp, Vibrio choerae, Vibrio para hemolyticus dan juga dapat disebabkan oleh makanan yang terkontaminasi, alergi dan malnutrisi (Amaliah, 2010). (Suprapto, 2017) berpendapat bahwa Diare adalah suatu penyakit dengan adanya tanda-tanda perubahan pada tinja yang lembek sampai mencair dan bertambahnya frekuensi BAB (buang air besar) 3 kali atau lebih dalam satu hari. Faktor yang mempengaruhi diare adalah lingkungan, gizi, kependudukan, pendidikan, sosial ekonomi dan perilaku masyarakat. Faktor terjadinya diare dapat dibagi menjadi tiga, yaitu faktor lingkungan, faktor individu dan faktor perilaku. Faktor lingkungan seperti kualitas air yang tidak bersih, lingkungan yang padat dan kurangnya ketersediaan sarana air bersih. Faktor individu seperti malnutrisi dan faktor perilaku seperti sanitasi dan hygiene makanan, buang air besar sembarangan, tidak mencuci tangan sebelum makan dan tidak mencuci peralatan makan sebelum digunakan (Utami, 2016).

Menurut hasil penelitian (Nurhaedah, 2019) bahwa terdapat hubungan yang signifikan antara penggunaan air bersih, jamban keluarga, pengelolaan sampah keluarga dan SPAL dengan kejadian diare pada lanjut usia. Sanitasi makanan ialah upaya yang bertujuan untuk melindungi keamanan pangan dengan tujuan untuk memutus rantai perkembangan 
mikroorganisme yang menjadi sumber penyakit (food borne disease). Pencegahan yang dapat dilakukan yaitu dari proses pemilahan bahan baku hingga makanan tersebut dihidangkan (Wati, 2018). Makanan yang tidak aman dapat menimbulkan penyakit yang di golongkan menjadi dua yaitu infeksi dan intoksikasi. Infeksi apabila mengkonsumsi makanan yang mengandung mikroorganisme, kemudian timbul gejala penyakit. Intoksikasi apabila mengkonsumsi makanan yang mengandung zat beracun dan menyebabkan keracunan makanan. Faktor yang dapat menyebabkan makanan menjadi tidak aman yaitu kontaminasi yang terdiri dari kontaminasi mikroorganisme, kontaminasi fisik, kontaminasi kimia serta kontaminasi radioaktif dan keracunan yang dapat disebabkan karena bahan makanan alami, infeksi mikroorganisme, racun, zat kimia dan alergi (Nurlaela, 2011).

Sanitasi makanan berkaitan erat dengan higiene dan tidak dapat dipisahkan. Higiene sendiri merupakan upaya kesehatan dalam menerapkan perilaku kebersihan subyeknya seperti kebersihan makanan, peralatan makan dan melindungi keamanan makanan. Prinsip higiene adalah menitikberatkan pada usaha dalam kesehatan hidup manusia. Prinsip sanitasi dan higiene perlu diterapkan untuk menjaga keamanan makanan (food safety) (Atmoko, 2017). Mikroorganisme yang menjadi salah satu penyebab diare adalah Escherichia coli atau yang sering disingkat E. coli merupakan bakteri yang secara normal berada pada tubuh manusia maupun hewan berdarah panas khusunya pada saluran pencernaan. Bakteri ini akan menjadi patogen apabila jumlahnya meningkat pada saluran pencernaan atau apabila bakteri ini berada diluar usus (Sanjaya, 2013). E. coli adalah bakteri dengan jenis spesies gram negatif, berbentuk batang pendek (coccobasil) dan dapat bergerak menggunakan flagella. E. coli juga menjadi indikator sanitasi makanan dan minuman karena keberadaan E. coli pada pada makanan dan minuman menunjukkan sanitasi yang tidak baik dan merupakan indikasi terjadinya kontaminasi tinja manusia pada air. E. coli yang terdapat pada makanan dan minuman dapat menimbulkan gejala penyakit seperti diare, kholera, gastroenteritis dan beberapa penyakit saluran pencernaan lainnya (Kurniadi, 2013).

\section{Metode}

Metode yang digunakan adalah menggunakan studi literatur dari berbagai jurnal internasional maupun nasional, metode ini digunakan untuk meringkas suatu topik yang berfungsi agar meningkatkan pemahaman terkini. Studi literatur menyajikan ulang materi yang diterbitkan sebelumnya, dan melaporkan fakta atau analisis baru dan tinjauan literatur memberikan ringkasan berupa publikasi terbaik dan paling relevan kemudian membandingkan hasil tersebut dalam artikel. Penelti menggunakan studi literatur dari jurnal yang terdiri dari jurnal nasional dan internasional yang didapatkan melalui google schoolar dengan membuka website google schoolar kemudian peneliti menuliskan kata kunci sesuai dengan MESH (Medical Subject Heading)

\section{Hasil Dan Pembahasan}

Diare dapat didefinisikan sebagai penyakit menular yang ditandai dengan gejala seperti perubahan bentuk dan konsistensi feses menjadi lembek hingga cair dan bertambahnya frekuensi buang air besar tiga kali atau lebih dalam sehari yang disertai muntah-muntah, sehingga menyebabkan kekurangan cairan (dehidrasi) yang apabila terlambat dalam melakukan tindakan akan dapat menyebabkan kematian (Kamilla, 2012). Diare dapat dibedakan menjadi dua yaitu, diare akut dan diare kronik. Diare akut merupakan diare yang gejalanya timbul secara tiba-tiba dan berlangsung selama kurang dari 14 hari, sedangkan diare kronik adalah diare yang berlangsung selama lebih dari 14 hari. Penyebab diare dapat berupa mikroorganisme seperti bakteri, virus, dan parasit serta 
dapat juga disebabkan oleh malnutrisi, makanan yang terkontaminasi dan alergi (Zein, 2004). Faktor risiko yang dapat menyebabkan diare adalah faktor lingkungan, faktor perilaku pada masyarakat, dan rendahnya pengetahuan masyarakat tentang diare. Faktor lingkungan contohnya kondisi sanitasi yang buruk dan sarana prasarana air bersih yang tidak memadai. Contoh pada faktor perilaku masyarakat seperti tidak mencucui tangan sebelum makan dan sesudah buang air besar serta melakukan pembuangan tinja secara sembarangan. Tidak memberikan ASI eksklusif selama 4 sampai 6 bulan pertama juga dapat menyebabkan resiko terkena diare lebih besar (Prawati, 2019).

Patofisiologi mekanisme terjadinya diare baik akut maupun kronik dibagi menjadi kelompok osmotik, sekretorik, eksudatif dan gangguan motilitas. Pada diare osmotik terjadi apabila terdapat bahan yang tidak dapat diserap oleh tubuh sehingga menyebabkan peningkatan osmolaritas dalam lumen yang menarik air dari plasma sehingga terjadi diare. Diare sekretorik terjadi apabila terdapat gangguan transport elektrolit baik absorpsi yang berkurang maupun sekresi yang meningkat. Hal tersebut dapat terjadi dikarenakan toksin yang dikeluarkan bakteri dan juga beberapa hormone intestinal seperti gastrin vasoactive intestinal polypeptide (VIP) yang juga dapat menyebabkan diare sekretorik. Pada diare eksudatif, inflamasi akan menyebabkan terjadinya kerusakan mukosa baik pada usus halus maupun usus besar. Inflamasi dan eksudasi tersebut dapat terjadi karena adanya infeksi bakteri yang bersifat non infeksi seperti gluten sensitive enteropathy, inflammatory bowel disease (IBD) atau akibat radiasi. Sedangkan pada gangguan motilitas dapat mengakibatkan waktu transit usus menjadi lebih cepat. Hal tersebut terjadi pada saat keadaan diabetes melitus, sindroma usus iritabel dan tritiksikosis (Zein, 2004).

Sanitasi merupakan salah satu faktor yang menjadi penyebab terjadinya diare. Sanitasi yang buruk dapat meningkatkan resiko terkena penyakit saluran pencernaan seperti diare hingga keracunan makanan. Sanitasi dapat didefinisikan sebagai upaya penciptaan dan pemeliharaan yang dapat mencegah terjadinya penyakit yang disebabkan oleh makanan. Sedangkan sanitasi makanan adalah suatu usaha pencegahan yang menitikberatkan kegiatan dan tindakan yang bertujuan untuk menghindari makanan dan minuman dari segala bahaya yang dapat mengganggu atau merusak kesehatan mulai dari makanan sebelum diproduksi hingga makanan disajikan (Atmoko, 2017).

Sanitasi dan higiene tidak dapat dipisahkan karena berkaitan sangat erat. Higiene adalah upaya dalam mencegah terjadinya penyakit yang menitikberatkan pada usaha individu dengan lingkungannya. Sanitasi memiliki arti yang mirip dengan higiene hanya berbeda pada fokus utamanya, jika higiene fokus pada aktivitas manusia, sedangkan sanitasi fokus pada lingkungan manusia, seperti contoh ketersediaan sarana air bersih. Hubungan sanitasi dan higiene sangat erat satu sama lain terlihat apabila higiene seseorang baik namun sanitasinya buruk maka akan menimbulkan resiko terjadinya penyakit atau efek lainnya akan tinggi. Misalnya higiene sudah baik karena mencuci tangan namun sanitasinya tidak mendukung karena kurangnya ketersediaan air bersih, maka mencuci tangan tidak sempurna (Rahmadhani, 2017).

Upaya dalam penerapan sanitasi makanan harus memperhatkan beberapa tahapan seperti keamanan dan kebersihan produk makanan yang di produksi, kebersihan individu dalam pengolahan makanan, keamanan terhadap penyediaan air, pengelolaan pembuangan air limbah dan kotoran, perlindungan makanan terhadap kontaminasi selama proses pengolahan penyajian serta penyimpanan, dan pencucian dan pembersihan peralatan dan perlengkapan (Atmoko, 2017). Sedangkan higiene makanan dilihat dari berbagai aspek, seperti kebiasaan, tempat pengelolaan makanan, dan peralatan pengelolaan makanan. Pada aspek kebiasaan yang dilihat adalah kebersihan penjamah makanan dalam 
pengolahan makanan yang aman dan sehat. Aspek tempat pengelolaan makanan harus memperhatikan sanitasi jasa boga, tersedianya air bersih, jamban dan urinoir, kamar mandi, tempat sampah serta tempat cuci tangan harus memenuhi syarat. Dan aspek peralatan pengelolaan makanan harus memiliki wadah makanan yang memiliki tutup, dan semua peralatan harus memenuhi syarat higiene sanitasi (Chantika, 2016).

Menurut teori kebutuhan Maslow, manusia memiliki kebutuhan dasar yaitu kebutuhan fisiologi salah satunya adalah kebutuhan makan karena untuk mempertahankan hidup (Islamy, 2018). Keamanan pangan memiliki definisi yaitu kondisi dan upaya yang diperlukan untuk mencegah makanan terhindar dari cemaran biologis, kimia maupun benda lain yang dapat mengganggu, dan membahayakan manusia. Makanan yang tidak aman dan dapat menyebabkan penyakit disebut foodborne disease yaitu gejala penyakit yang timbul akibat mengkomsumsi makanan yang terkontaminasi bahan/senyawa beracun atau organisme patogen. Faktor yang menyebabkan makanan menjadi tidak aman adalah kontaminasi yang terdiri dari empat macam yaitu kontaminasi mikroba (bakteri, jamur, dan cendawan), kontaminasi fisik (rambut, debu, tanah, serangga dan kotoran lainnya), kontaminasi kimia (pupuk, pestisida, merkuri, arsen, cyianida dan sebagainya) dan kontaminasi radioaktif (radiasi, sinar alfa, sinar gamma, radio aktif, sinar cosmis dan sebagainya). Terjadinya kontaminasi dapat dibagi dalam tiga cara, yaitu kontaminasi langsung (direct contamination), kontaminasi silang (cross contamination) dan kontaminasi ulang (recontamination) (Nurlaela, 2011).

Salah satu mikroorganisme yang menjadi penyebab tersering diare adalah Escherichia coli atau yang sering disingkat menjadi E. coli. Syarat E. coli dalam SNI 01-6366-200 harus negatif. Pada manusia bakteri E. coli yang sering menyebabkan diare dikelompokkan menjadi empat, yaitu enterotoksigenik E. coli (ETEC), enteroinvasif E. coli (ETEC), enteropatogenik E. coli (EPEC), dan enterohemoragik E. coli (EHEC). E. coli menempel pada sel usus manusia dan memproduksi enterotoksin dimana enterotoksin tersebut akan mempengaruhi sekresi cairan saluran pencernaan melalui konsentrasi cyclic AMP (cAMP) ataupun cGMP. Pada saluran pencernaan EPEC akan menyebabkan atrofi dan nekrosis usus. EPEC akan menyebabkan diare terutama pada anak-anak, sedangkan EHEC akan membentuk koloni pada saluran pencernaan dan menyebabkan terjadinya atrofi pada selsel epitel usus (Suwito, 2010).

Berdasarkan penelitian yang dilakukan Wati et al., (2018) didapatkan hasil tidak adanya hubungan yang bermakna antara sanitasi makanan dengan kejadian diare pada balita. Hal tersebut dikarenakan perilaku sanitasi makanan yang sudah diterapkan dengan baik dan juga tingkat pengetahuan orang tua mengenai sanitasi makanan juga sudah baik sehingga orang tua dapat memilih makanan yang baik untuk dikonsumsi dan sesuai dengan kebutuhan balita. Selain itu pola sanitasi makanan yang baik juga didukung oleh pemahaman orang tua yang baik tentang sanitasi makanan. Namun hal ini tidak sejalan dengan penelitian yang dilakukan oleh Setiyabudi \& Setyowati (2016) didapatkan hasil bahwa sanitasi makanan berhubungan dengan kejadian diare yang artinya individu yang memiliki sanitasi makanan memiliki peluang lebih besar untuk terkena diare. Penanganan makanan yang tidak benar juga menjadi penyebab diare seperti contoh tidak mencuci sayuran dan buah dengan cara yang benar, sehingga berisiko terkontaminasi bakteri kembali. Hal ini menunjukkan bahwa sanitasi makanan juga bergantung pada tingkat pengetahuan mengenai penitngnya sanitasi dan higiene tiap individu.

Berdasarkan penelitian yang dilakukan Musawir \& Arsin (2014) didapatkan hasil tabulasi silang antara Escherichia coli pada botol susu dengan kejadian diare bahwa sebanyak 21 bayi $(77,8 \%)$ mengalami diare dengan botol susu yang terkontaminasi E. coli dan sebanyak 10 bayi $(14,1 \%)$ mengalami diare dengan botol susu tidak terdapat E. coli. Hal 
ini memperlihatkan adanya pengaruh yang kuat antara kontaminasi E. coli dengan penyakit diare. Hal ini sejalan dengan penelitian yang dilakukan oleh Halim et al., (2017) dimana didapatkan hasil dari 50 sampel penderita diabetes akut yang diambil mikroorganisme penyebabnya adalah E. coli sebanyak 25 (50\%) dan diikuti oleh Coccus Gram negative 6 sampel, Klebsiella sp 6 sampel, Staphylococcus hemoliticus 1 sampel, Yersinis pseudotuberculosis 1 sampel, Streptococcus hemoliticus 1 sampel, Providencia vettger 1 sampel, Proteus stuartii 1 sampel, Streptococcus sp 1 sampel dan Pseudomonas sp 1 sampel, sedangkan 7 sampel tidak didapatkan pertumbuhan kuman.

Berdasarkan hasil pengumpulan dari artikel dan jurnal serta analisa penulis maka didapatkan bahwa sanitasi dan kontaminasi Escherichia coli sangat berpengaruh pada kejadian penyakit diare. Sanitasi lingkungan serta faktor perilaku yang buruk menjadi awal penyebab suatu makanan dapat terkontaminasi. Hasil penelitian yang dilakukan oleh WHO (2010) didapatkan bahwa pemanfaatan jamban, cuci tangan menggunakan sabun, dan pengelolaan air rumah tangga dengan baik dapat menurunkan angka kejadian diare sebesar 32\%, 45\%, dan 39\% (Surya, 2019). Hal ini juga sejalan dengan hasil penelitian yang dilakukan Hasifah (2018) didapatkan hasil adanya hubungan antara sanitasi makanan dengan kejadian diare dimana sanitasi makanan yang buruk dipengaruhi juga dengan tingkat kesadaran masyarakat untuk menjaga kebersihan makanan, misalnya cara penyimpanan makanan yang biasanya diatas meja dengan keadaan terbuka, hal inilah yang menyebabkan makanan tersebut terkontaminasi bakteri salah satunya adalah Escherichia coli, yang kemudian dikonsumsi dan pada akhirnya menimbulkan gejala diare.

\section{Simpulan Dan Saran}

Sanitasi makanan memiliki pengaruh yang cukup kuat terhadap terjadinya diare. Hal ini juga dapat dipengaruhi oleh tingkat pengetahuan setiap individu mengenai pentingnya menciptakan dan memelihara serta menjaga sanitasi dan higiene baik per individu maupun lingkungan sekitarnya. Sanitasi makanan harus memperhatikan setiap prosesnya mulai dari sebelum makanan diproduksi hingga makanan disajikan. Mikroorganisme Escherichia coli merupakan bagian dari microflora yang normal berada pada saluran pencernaan dan menjadi patogen bila berada di luar saluran pencernaan dan juga menjadi penyebab tersering penyakit diare, dimana sering terjadi pada orang yang kurang memperhatikan kebersihan menyebabkan mudahnya terkontaminasi bakteri E. coli baik melalui kontaminasi langsung (direct contamination), kontaminasi silang (cross contamination) maupun kontaminasi ulang (recontamination)

\section{Daftar Rujukan}

Arda, D., Hartaty, H., \& Hasriani, H. (2020). Studi Kasus Pasien dengan Diare Rumah Sakit di Kota Makassar. Jurnal Ilmiah Kesehatan Sandi Husada, 11(1), 461-466.

Ahmad, R. (2017). Kontaminasi Bakteri Escherichia coli Pada Makanan Jajanan Di Pasar Mardika Kota Ambon. Global Health Science, 2(1)

Amaliah, S. (2010). Hubungan Sanitasi Lingkungan dan Faktor Budaya Dengan Kejadian Diare Pada Anak Balita Di Desa Toriyo Kecamatan Bendosari Kabupaten Sukoharjo. Prosiding Seminar Nasional Unimus

Atmoko, T. P.H. (2017). Peningkatan Higiene Sanitasi Sebagai Upaya Menjaga Kualitas Makanan Dan Kepuasan Pelanggan Di Rumah Makan Dhamar Palembang. Jurnal Khasanah Ilmu, 8(1)

Chantika, I., Sumardianto, D., \& Sumaningrum, N.D. (2016). Higiene Penjamah dan Sanitasi Pengelolaan Makanan Di Instalasi Gizi Rumah Sakit Umum Daerah Gambiran Kota Kediri. Jurnal Preventia, 1(1) 
Hasifah. (2018) Hubungan Sanitasi Makanan dan Jamban Keluarga Dengan Kejadian Diare Di Wilayah Kerja Puskesmas Bontonompo I Kab. Gowa. Jurnal Ilmiah Kesehatan Diagnosis, 12(1)

Islamy, G.P., Sumarmi, S., \& Farapti. (2018). Analisis Higiene Sanitasi dan Keamanan Makanan Jajanan di Pasar Besar Kota Malang. Amerta Nutrition, 2(1), 29-36. http://doi.org/10.2473/amnt.v2i1.2018.29-36

Kamilla, L., Suhartono., \& Nur, W.E. (2012). Hubungan Praktek Personal Hygiene Ibu dan Kondisi Sanitasi Lingkungan Rumah dengan Kejadian Diare pada Balita di Puskesmas Kampung Dalam Kecamatan Pontianak Timur. Jurnal Kesehatan Lingkungan Indonesia, 11(2)

Kemenkes RI. (2011). Buku Saku Petugas Kesehatan Lintas Diare. Jakarta: Direktorat Jenderal Pengendalian Penyakit dan Penyehatan Lingkungan

Kemenkes RI. (2011). Buletin Jendela Data dan Informasi Kesehatan. Jakarta: Kementerian Kesehatan Republik Indonesia

Kuniadi, Y., Saam, Z., Afandi, D. (2013). Faktor Kontaminasi Bakteri E. coli Pada Makanan Jajanan Di Lingkungan Kantin Sekolah Dasar Wilayah Kecamatan Bangkinang. Jurnal Ilmu Lingkungan, 7(1)

Lailatul, M. (2013). Ketersediaan Sarana Sanitasi Dasar, Personal Hygiene Ibu dan Kejadian Diare. Jurnal Kesehatan Masyarakat, 8(2), 167-73

Musawir, M.A., \& Arsin, A.A. (2014). Kontaminasi Bakteri Escherichia coli Pada Botol Susu Dengan Kejadian Diare Pada Bayi. Jurnal MKMI, 146-153

Ningsih, R. (2014). Penyuluhan Hygiene Sanitasi Makanan Dan Minuman, Serta Kualitas Makanan Yang DiJajakan Pedagang Di Lingkungan SDN Kota Samarinda. Jurnal Kesehatan Masyarakat, 10(1), 64-72

Nurlaela, E. (2011). Keamanan Pangan Dan Perilaku Penjamah Makanan Di Instalasi Gizi Rumah Sakit. Media Gizi Masyarakat Indonesia, 1(1), 1-7

Nurhaedah, N. (2019). Hubungan Antara Sanitasi Lingkungan Dengan Kejadian Diare Pada Lanjut Usia. Jurnal Ilmiah Kesehatan Sandi Husada, 9(1), 29-31.

Prawati, D.D., Haqi, D.N. (2019). Faktor Yang Mempengaruhi Kejadian Diare Di Tambak Sari, Kota Surabaya. Jurnal Promkes: The Indonesian Journal Of Health Promotion and Health Education, 7(1), 34-45. http://doi.org/10.20473/jpk.V7.I1.2019.34-45

Ramadhani, D., Sumarni, S. (2017). Gambaran Pemerapan Prinsip Higiene Sanitasi Makanan Di PT Aerofood Indonesia, Tangerang, Banten. Amerta Nutrition, 1(4), 291-299. http://doi.org/10.2473/amnt.v1i4.2017.291-299

Sanjaya, T. A., \& Apriliana, E. (2013). Deteksi Escherichia coli Pada Jajanan Cendol Yang Dijual Di Pasar Tradisional Kota Bandar Lampung. MAJORITY (Medical Journal Of Lampung University).

Setiyabudi, R., \& Setyowati, V. (2016). Penyediaan Air Bersih, Penggunaan Jamban Keluarga, Pengelolaan Sampah, Sanitasi Makanan Dan Kebiasaan Mencuci Tangan Berpengaruh Terhadap Kejadian Diare Umur 15-50 Th. MEDISAINS: Jurnal Ilmiah Ilmu-Ilmu Kesehatan, 14(2)

Sidhi, A.N., Raharjo, M., \& Dewanti, N.A.Y. (2016). Hubungan Kualitas Sanitasi Lingkungan dan Bakteriologis Air Bersih Terhadap Kejadian Diare Pada Balita Di Wilayah Kerja Puskesmas Adiwerna Kabupaten Tegal. Jurnal Kesehatan Masyarakat, 4(3)

Surya, J. (2010). Sanitasi Total Berbasis Masyarakat (STBM) Dengan Diare Pada Balita. Jurnal Ilmiah Kesehatan Sandi Husada, 10(2), 281-284

Suprapto, N. (2017). Hubungan Sanitasi Lingkungan Dengan Kejadian Diare Pada Lanjut Usia Di Kelurahan Barombong Kecamatan Tamalate Kota Makassar. Jurnal Ilmiah Kesehatan Sandi Husada, 5(2), 47-64.

Suwito, W. (2010). Bakteri Yang Sering Mencemari Susu: Deteksi, Patogenesis, Epidemiologi, Dan Cara Pengendaliannya. Jurnal Litbang Pertanian, 29(3) 
Utami, N., \& Luthfiana, N. (2016). Faktor-Faktor yang Mempengaruhi Kejadian Diare Pada Anak. MAJORITY (Medical Journal Of Lampung University), 5(4)

Wati, F., Handayani, L., \& Arzani. (2018). Hubungan Personal Hygiene Dan Sanitasi Makanan Dengan Kejadian Diare Pada Balita Di Puskesmas Umbulharjo I Yogyakarta. Formil (Forum Ilmiah) KesMas Respati, 3(2)

World Health Organization (WHO). (2010). The Treatment Of Diarrhea. Ganeva

Zein, U., Sagala, K.H., \& Ginting, J. (2004). Diare Akut Disebabkan Bakteri. e-USU Repository 